\title{
大画面高精細強誘電性液晶ディスプレイの特性
}

\section{Characteristics of the Large Size, High Resolution FLCD}

$\begin{array}{lll}\text { 坪 山 } & \text { 明 }^{\dagger} & \text { 羽 生 由紀夫 }{ }^{\dagger}, \\ \text { 吉 原 } & \text { 諭 }^{\dagger}, & \text { 神 辺 純一郎 }\end{array}$

$1024 \times 1280$ 画素の白豊およびカラーFLCD（強誘電性液晶ディスプレイ）を開発した 新規な配 向技術と駆動法を採用し，高デューティ駆動で，高画質(高速，高コントラスト，広視野角)を実現 した FLC配向モデルおよび電気光学応答を中心に解説する

\section{1. まえがき}

表面安定化強誘電性液晶素子（SSFLCD）の原理が Clark と Lagerwallによって提唱されて以来 ${ }^{1)}$, 多く の研究開発グループが, この技術をディスプレイに適 用しようと努力を続けてきた SSFLC は高速応答や そのメモリー性に由来する高デューティ駆動が可能な ど, 優れた特徵を持っているしかし, ネマティック 液晶より秩序度の高いスメクティック相で発現する FLC を制御するためには, 技術的に高い壁が数多く あった それは, 大面積の無欠陥配向技術や耐衝撃性 問題等である

我々は 1989 年に, 基本的ないくつかの問題を解决 して 14 インチ $1120 \times 1280$ 画素を持つ液晶ディスプレ イを発表し, SSFLC技術の高い可能性を示した ${ }^{21}$ しかし，このディスプレイは，コントラストが不充分 で ( 5 程度), カラー化をすることは困難であった 我々は, 高輝度・高コントラストを実現するため, SSFLCの配向技術の向上に注力し改善を図った 本 論文では, 大面積の安定な配向を実現する配向技術の 基本的な考え方を議論し, 電気光学特性を中心に FLCティスプレイの特性を解説する

\section{2. 実験}

FLCD で高輝度・高コントラストを達成するために

†キヤノン株式会社 ティスプレイ事業推進センター

$\dagger$ Display Business Operation Center, Canon Inc, Kana gawa

590 (34)
表 1 強誘電性液晶の物性パラメー夕 (at $\left.30^{\circ} \mathrm{C}\right)$

\begin{tabular}{|c|c|}
\hline 相転移愠度 $\left({ }^{\circ} \mathrm{C}\right)$ & Iso $\frac{95}{-} \mathrm{N}^{*} \stackrel{85}{-} \mathrm{SmA} \stackrel{68}{-} \mathrm{SmC}^{*} \underset{-25}{\stackrel{-15}{\longrightarrow}}$ Cryst \\
\hline$\Delta \varepsilon$ （誘電率異方性） & -03 \\
\hline$\theta$ (コーン角) & $15^{\circ}$ \\
\hline$P_{s}($ 自発分極 $)$ & $58 \mathrm{nc} / \mathrm{cm}^{2}$ \\
\hline
\end{tabular}

は, “ユニフォーム配向 (液晶分子が基板法線方向でね じれていない配向)”を実現することが不可欠である 我々が採用している高コントラスト配向をより明確に 説明するため, 以下の実験を行った

\section{1 液晶材料}

液晶材料は, ノンカイラルのピリミジン骨格の液晶 を主成分とし, カイラルのフッ素化液晶を添加して調 整したこの液晶の $30^{\circ} \mathrm{C}$ 物性パラメータを表 1 に 示す

\section{2 実験セル}

我々は，2つの特徵的な配向を比較するために，2 種類の異なる有機配向膜で液晶セルを作製したこれ ら Cell-A と Cell-B のプレチルト角はそれそれ $18^{\circ}$ と 3であるセルの構造を図1に示す配向膜層は ITO 電極上に設けられ, それぞれ対向面と同方向に ラビング処理した セルギャップはビーズスペーサを 用いて $14 \mu \mathrm{m}$ に設定した プレチルト角は, クリス タルローテーション法で測定した その際用いた液晶 は, 室温て $\mathrm{SmA}$ 相を持つノンカイラル液晶で, その テレヒション学会誌 Vol 47, No 5, pp 590～594 (1993) 


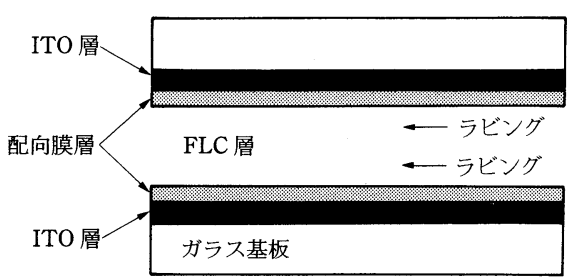

図 1 実験セル断面図

主成分は本実験に用いた FLC 材料のピリミジン液晶 である。

\subsection{FLC 配向}

(1) 顕微鏡観察

これらのセルの直交ニコル下の顕微鏡写真を写真 1 に示す．どちらのセルも配向欠陥のない良好な配向が 得られていることがわかる。液体相から冷却後の初期 状態に，ディスクリネーションラインによって隔てさ れている 2 つの光学状態がほぼ等量混在することは, 良好な双安定状態が実現されていることを示唆してい る. Cell-A の消光位は充分な遮光がなされているが, Cell-B は充分ではなく灰色に近い状態である。さら

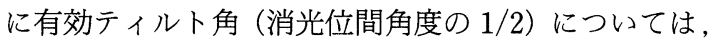
Cell-A は材料の持つ固有のティルト角 $\left(15^{\circ}\right)$ とほほ同 じ值を示すが, Cell-Bは $7^{\circ}$ と小さい.

（2）配向構造モデル

これらの配向モデルを示したものが図 2 である. 強 誘電性液晶は層構造を持ち, 平行配向処理されたセル 内においては，図のようなシェブロン構造を持つこと が知られている，先の論文で我々は，このシェブロン 構造の方向とラビング処理の方向から，2 種類のシェ ブロン構造のモデルを提示した。 それが $\mathrm{Sm}^{*} \mathrm{C} 1$ と

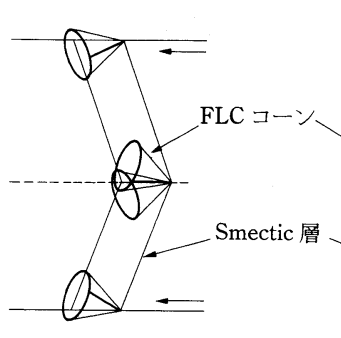

$\mathrm{Sm} * \mathrm{C} 1$ 構造

$\alpha<\theta+\delta$

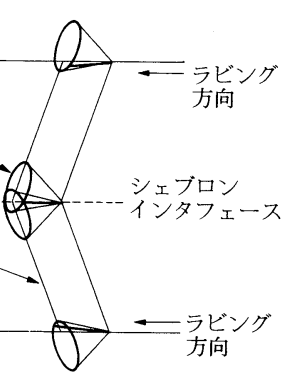

$\mathrm{Sm} * \mathrm{C} 2$ 構造 $\alpha<\theta-\delta$
( $\alpha$ : プレチルト角, $\theta$ : コーン角, $\delta$ :層傾き角 $)$

図 2 シェブロン配向モデル

$\mathrm{Sm}^{*} \mathrm{C} 2$ である（以降 C $1 \cdot \mathrm{C} 2$ と略記）。これらの構造 は, ビーズスペーサの周囲の微小な欠陥の構造や, 液 晶の冷却過程のテクスチャ変化を観察することで判別 できる，それぞれの構造の許容条件を図の下に示し た.これらの条件は, プレチルト角 $(\alpha)$, コーン角 $(\theta)$, 層傾き角 $(\delta)$ によって規定され，「配向膜界面の 液晶分子が, FLC コーン上に包含される」条件を幾何 学的に算出したものである. $\theta-\delta$ の值は高々 $3^{\circ}$ なの で, Cell-Aのような高プレチルトセルでは，C2 構 造は許容されない.したがって Cell-Aにおいては, $\mathrm{C} 1$ 構造のみが安定化される.

一方，このモデルの許容条件からは，低プレチルト の Cell-B は, C 1 と C 2 両方の構造が許容されるが, 顕微鏡観察においては，C2 のみが観察されている. このことは, 図 3 に示した低プレチルトセルのc-ダ イレクタプロファイルで説明できる．このモデルで は, 界面と自発分極の相互作用により界面付近の液晶

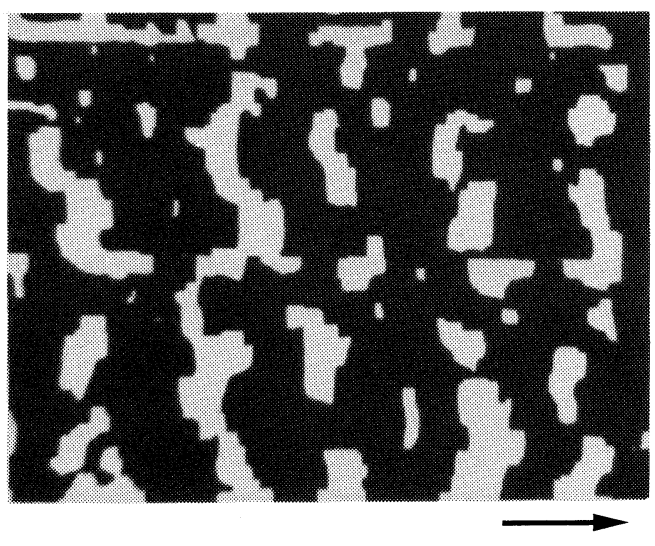

(a) Cell A

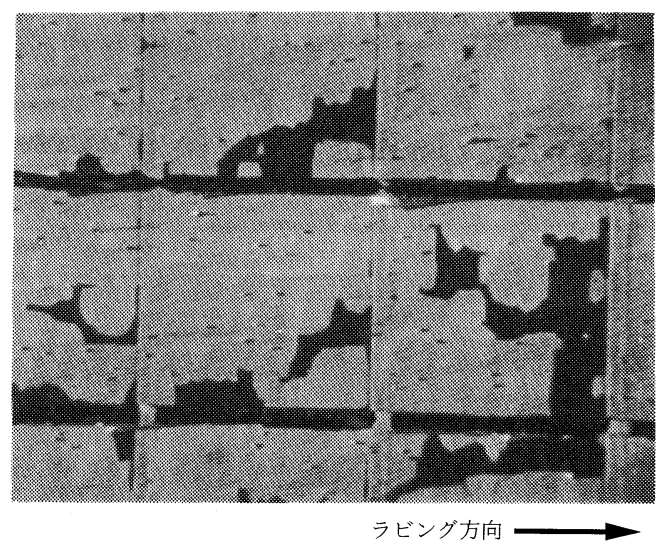

(b) Cell B

写真 1 偏光顕微鏡による配向状態写真 


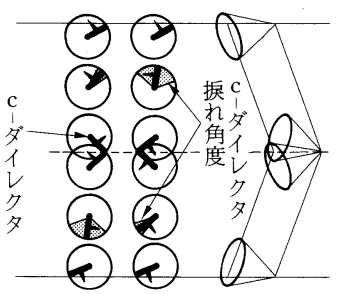

C1-Splay

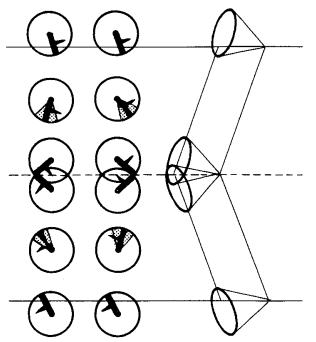

C2-Splay
図 3 低プレチルトセルにおけるc-ダイレクタプロ ファイル

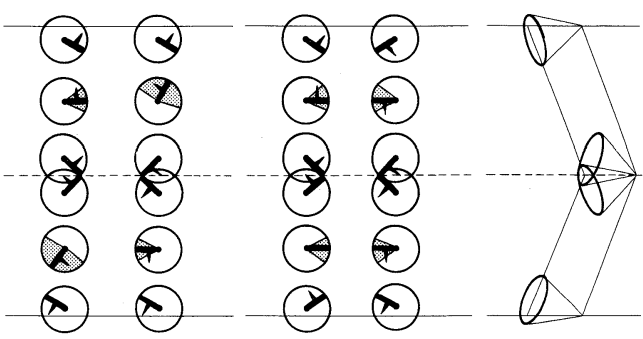

C1-Splay

C1 Uniform

図 4 高プレチルトセルに拈ける c-ダイレクタプロ ファイル

分子が固定されているため, c-ダイレクタに捩れが生 じる. 図 3 中に示した界面からシェブロンインタフェ ースまでのc-ダイレクタの㨝れる角度から明らかな ように，C1の局所的な歪みエネルギーはC 2 のそれ より大きい.したがって，C 2-スプレイ構造が CellBにおいては安定になる。

図 4 に高プレチルト配向におけるスプレイとユニフ オーム構造を示した. 同じように 2 つの構造の弾性エ ネルギー差を考えてみる。図 4 のc-ダイレクタ据れ 量から明らかなように, ユニフォーム配向がより安定 である、しかしながら一般的には，界面と自発分極の 強い相互作用によってスプレイ配向をとる場合が多 い. ユニフォーム配向を実現する配向処理は, スメク チック層を整然と配向させるのみではなく, 液晶分子 との界面相互作用の小さいことが重要である. 我久 は, 配向膜材料と配向処理を最適化することで，安定 なユニフォーム配向を実現することができた。

\section{（3）駆動配向劣化}

実際のディスプレイには，C 1-ユニフォーム配向を 採用したが，実用上問題が発生した。それは充分にプ レチルト角が高くない場合, C 2 禁止条件を満足して いても, 時分割駆動中にC 2 構造が発生し画質が低下

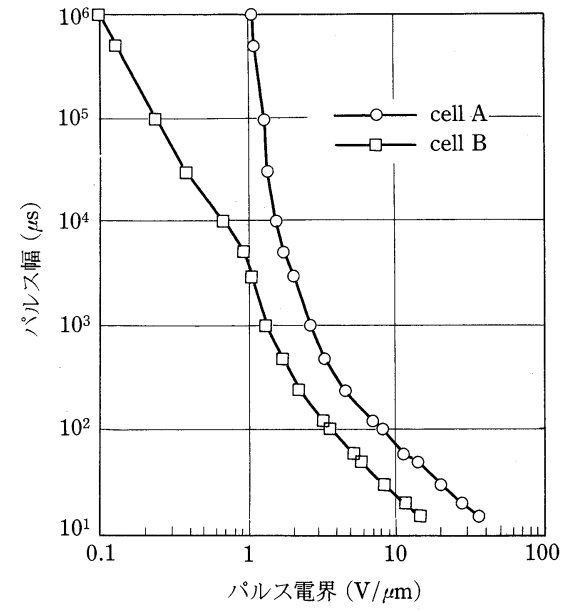

図 5 閾値特性曲線（スイッチングパルス幅 vsパル 又電界)

するという問題である.プレチルト角 $\alpha$ とコーン角 $\theta$ を種々組合せた実験から， $\alpha>\theta$ という条件を導入 することで効果的に C 2 発生が抑制できた.この付加 条件によって, 駆動時の配向劣化のない安定したユニ フォーム配向が実現できた。

\section{4 電気光学応答}

（1）閾値特性

図5に Cell-A と B の閾值特性を示す。縦軸は双安 定スイッチングが可能なパルス信号幅を示し, 横軸は その電圧值を示す，スイッチングパルスは単極性パル スである．ここで特に注目したいのがパルス幅の長い レンジ（100 ms 以上）の閾値特性の差である. Cell-A の閾値電圧はこのレンジにおいてパルス幅依存性は非 常に少なく，かつCell-Bの閾值より約 1 桁大きい. Cell-Aのように大きなパルス幅のレンジでの閾值電 圧が大きくかつ安定していることは, 良好なスイッチ ング特性をもつセル設計において非常に重要である.

（2）反電場

FLC が自発分極の反転を伴ってスイッチングをす るとき，その分極を補償するために偏在していた液晶 中のイオンが内部電場を作る。この反電場が FLCの 安定状態間のスイッチングを阻害する ${ }^{3)}$. この反電場 は以下の式で表すことができる。

$$
\begin{aligned}
& V_{r e v}=\frac{2 P_{s}}{C_{i n s}+C_{L C}} \exp \left\{\frac{-t}{\left(C_{i n s}+C_{L C}\right) R_{L C}}\right\} \\
& V_{r e v}: \text { 反電圧 } \\
& C_{i n s}: \text { 絶縁層の静電容量 } \\
& C_{L C}: \text { 液晶層の静電容量 } \\
& R_{L C} \text { : 液晶層の抵抗 }
\end{aligned}
$$




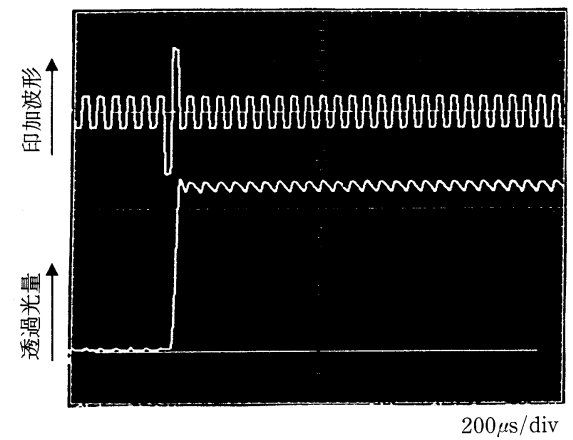

(a) cell-A

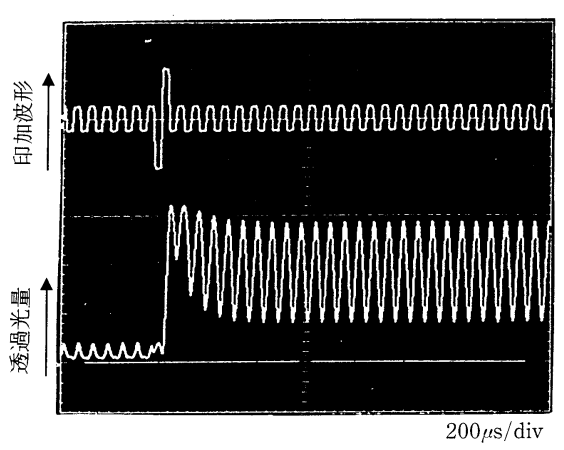

(b) cell-B

図 6 時分割駆動波形に対する光学応答

もし，このスイッチングの直後に発生する反電場が FLCの閾值より大きい場合, FLC は双安定状態のス イッチングをすることができず，もとの状態に戻され る。つまり双安定性は失われる。

ところで, 大面積の FLCD を生産する上では，上 下電極間の異物による導通を避けるために, 透明電極 上に保護層を設ける必要がある。保護層として一般的 な無機材料を用いた場合, $0.1 \mu \mathrm{m}$ の層厚と仮定して,

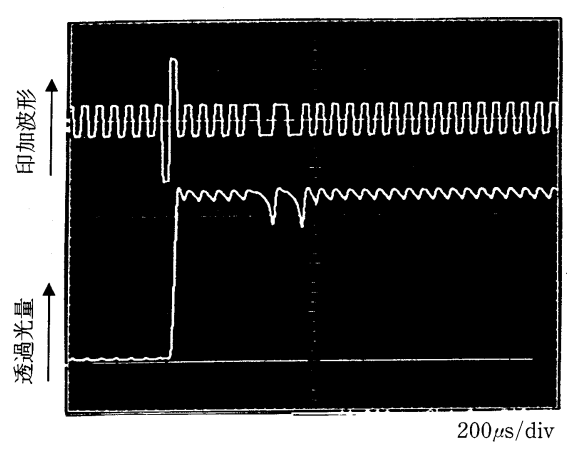

図 7 Cell-A の画像表示を想定した光学応答

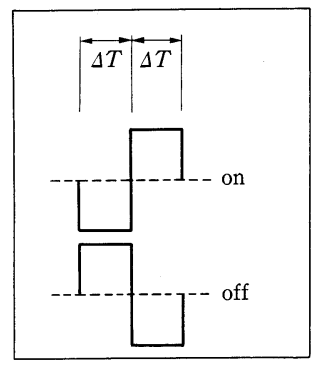

(a) 一般的な波形

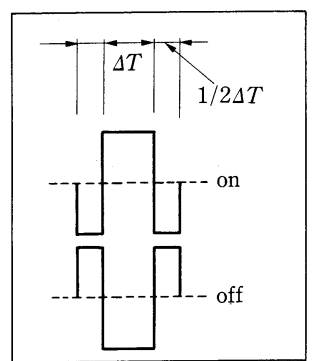

(b) クロストークを 解消する新規な波形
図 8 情報信号波形
反電場の時定数は数秒である.この時間レンジのパル ス幅に対する閾值電圧が高い Cell-A の配向は，充分 な保護層をセル内に設定したとしても，良好な双安定 スイッチング特性が得られる。 Cell-Aのような閾値 特性は, 大面積 FLCD に高い生産性を与える。

(3) 電気光学応答

図 6 にCell-A おょびCell-B の電気光学応答を示 す。印加波形は 2 スロット駆動波形である. 図から Cell-Aのスイッチング後の光学強度の保持状態, お よび非選択時の ACバイアス電圧に対する安定性が良 いことは明らかで, Cell-A が高コントラストを持つ ことを示している.

\section{5 駆動波形の改善}

(1) クロストーク

図 7 に，ある画像を表示した場合を想定したCell$\mathrm{A}$ の光学応答, 図 $8(\mathrm{a})$ に, この時用いた一般的な情 報信号波形を示した。この情報信号は，走查信号の書 込みパルスと同期し，それと同じパルス幅 $\Delta T$ を持 つ双極性パルスである。この信号の“on”と“off” が連なる場合, $2 \Delta T$ 成分が発生し, 大きな光量変動

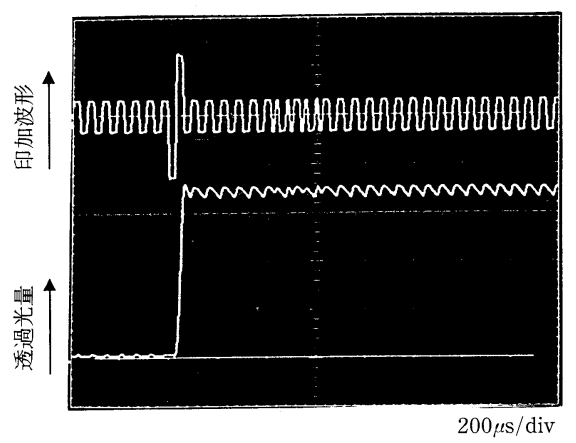

図 9 Cell-A の画像表示を想定した光学応答 （新規な情報信号 (図 8 (b))を用いた場合) 
表 2 ディスプレイ仕様

\begin{tabular}{|c|c|c|}
\hline & モノクロ & カラー \\
\hline 画 素 数 & \multicolumn{2}{|c|}{$1024 \times 1280$} \\
\hline コントラスト & \multicolumn{2}{|c|}{40 以上 } \\
\hline 表 示 面 積 & \multicolumn{2}{|c|}{ 対角 15 インチ } \\
\hline 応 答 速 度 & \multicolumn{2}{|c|}{$\begin{array}{c}14 \mathrm{~Hz} / \text { frame } \\
70 \mu \mathrm{s} / \text { line }\end{array}$} \\
\hline 画 素 構 成 & $2: 3$ 分割 & RGBW \\
\hline 階 調 ／色数 & 4 レベル & 16 色 \\
\hline 駆 動 電 圧 & \multicolumn{2}{|c|}{ $\pm 20 \mathrm{~V}$} \\
\hline
\end{tabular}

が生じる。これに起因して，FLCD 上に表示パター ンに依存したフリッカやコントラスト変動が起きる. この現象は FLC 特有のクロストーク現象である.

（2）情報信号波形の改良

このクロストークを回避するため，新しい情報信号 波形（図 $8(\mathrm{~b})$ ) を考案した。この情報信号を用いた 場合の光学応答を図 9 に示す. $\Delta T$ パルスの前後に $1 / 2 \Delta T$ 幅のパルスを導入することで, DC成分を補 償すると同時に, 情報信号のつながりによる $2 \Delta T$ 成 分発生を解消することができる，この情報信号によっ て得られる光学応答は, 非選択時に大きな光量変動が なく, クロストークやコントラスト減少等の画質劣化 が解消できる.

\section{6 ディスプレイ特性}

以上述べてきた材料, 配向, 駆動技術を用いて達成 したディスプレイ仕様を表 2 に示す. 図 10 にコント ラストの視角依存性を示した。広い視角にわたって高 コントラストが保たれている。

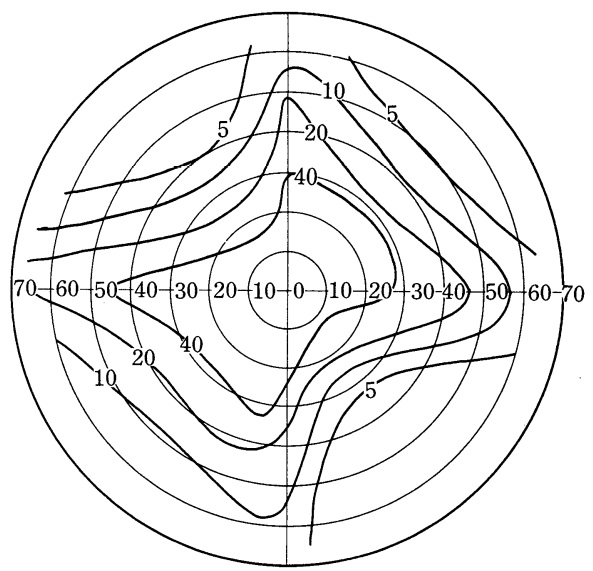

図 10 モノクロディスプレイのコントラストの視角 依存性

\section{3. む す び}

単純マトリクス構成で高画質・高パフォーマンスの FLCD が，新規な配向手法と駆動技術を導入するこ とによって達成された。我々は, 近い将来, FLCD が多くの分野のディスプレイに応用されることを確信 している.

(1992 年 11 月 20 日受付)

\section{〔参 考 文 献〕}

1) N. A. Clark and S. T. Lagerwall ; Appl. Phys. Lett., 36, p. 899 (1980)

2) J. Kanbe, H. Inoue, A. Mizutome, Y. Hanyu, K. Katagiri and S. Yoshihara: Ferroelectrics, 114, p. 3 (1991)

3) Y. Inaba, K. Katagiri, H. Inoue, J. Kanbe, S. Yoshihara and S. Iijima : Ferroelectrics, 85, p. 225 (1988)

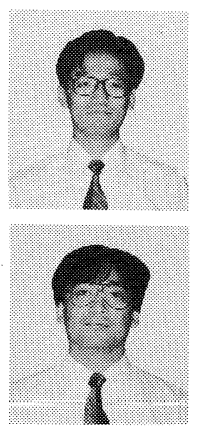

\begin{abstract}
恬山ま 严山明昭和 58 年, 北海道大学理学 部修士課程修了. 同年, キャノン (株) に入 社. 以来, 液晶の物性・電気光学応答を中心 に, ディスプレイの研究開発に従事. キャノ ン平塚ディスプレイ事業推進センター所属.
\end{abstract}

羽生由紀势 昭和 60 年, 筑波大学大学院 博士課程化学研究科修了. 同年, キャノン (株)に入社. 以来, 強誘電性液晶の配向制御 技術を中心にディスプレイの研究開発に従 事. キャノン平塚ディスプレイ事業推進セン 夕一所属. 主任研究員. 理学博士.

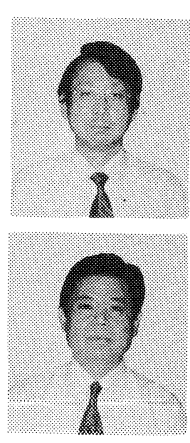

咭原詥昭和 48 年, 横浜国立大学工 学部修士課程修了. 同年, キヤノン (株)に入 社. 生産技術分野を中心に, カメラ用光学素 子開発を担当した後, 液晶ディスプレイの研 究開発に従事. 平塚事業所内ディスプレイ事 業推進センター所属.

\section{がんべじゅんいらう}

神辺純一郎 昭和 52 年, 東京教育大学光 学研究所博士課程修了. 同年, キャノン(株) 入社. 複写機の現像プロセスの開発, 感光ド ラムの開発の後, 強誘電性液晶ディスプレイ の開発に着手. 現在に至る.ディスプレイ事 業推進センター所属. 